\title{
2015 American Working Conditions Survey: Focus on Older Versus Younger Workers
}

Nicole Maestas, Kathleen J. Mullen, David Powell, Jeffrey Wenger, and Till von Wachter 


\title{
2015 American Working Conditions Survey: Focus on Older Versus Younger Workers
}

\author{
Nicole Maestas \\ Harvard University \\ Kathleen J. Mullen \\ RAND \\ David Powell \\ RAND \\ Jeffrey Wenger \\ RAND \\ Till von Wachter \\ University of California-Los Angeles \\ December 2016
Michigan Retirement Research Center
University of Michigan
P.O. Box 1248
Ann Arbor, MI 48104
www.mrrc.isr.umich.edu

(734) 615-0422

\section{Acknowledgements}

The research reported herein was performed pursuant to a grant from the U.S. Social Security Administration (SSA) funded as part of the Retirement Research Consortium through the University of Michigan Retirement Research Center Award RRC08098401. The opinions and conclusions expressed are solely those of the author(s) and do not represent the opinions or policy of SSA or any agency of the federal government. Neither the United States Government nor any agency thereof, nor any of their employees, makes any warranty, express or implied, or assumes any legal liability or responsibility for the accuracy, completeness, or usefulness of the contents of this report. Reference herein to any specific commercial product, process or service by trade name, trademark, manufacturer, or otherwise does not necessarily constitute or imply endorsement, recommendation or favoring by the United States Government or any agency thereof.

\section{Regents of the University of Michigan}

Michael J. Behm, Grand Blanc; Mark J. Bernstein, Ann Arbor; Laurence B. Deitch, Bloomfield Hills; Shauna Ryder Diggs, Grosse Pointe; Denise Ilitch, Bingham Farms; Andrea Fischer Newman, Ann Arbor; Andrew C. Richner, Grosse Pointe Park; Katherine E. White, Ann Arbor; Mark S. Schlissel, ex officio 


\title{
2015 American Working Conditions Survey: Focus on Older Versus Younger Workers
}

\begin{abstract}
In this report we highlight findings on the differing job demands of older versus younger workers from the 2015 American Working Conditions Survey (AWCS), a new nationally representative survey of U.S. workers ages 25-71. We find that generally older workers (over age 50) report better working conditions than younger workers, with some exceptions (e.g., on-the-job training, prospects for career advancement).
\end{abstract}

\section{Citation}

Maestas, Nichole, Kathleen J. Mullen, David Powell, Jeffrey Wenger, and Till von Wachter. 2016. “2015 American Working Conditions Survey: Focus on Older Versus Younger Workers.” Ann Arbor, MI. University of Michigan Retirement Research Center (MRRC) Working Paper, WP 2017-362. http://www.mrrc.isr.umich.edu/publications/papers/pdf/wp362.pdf

\section{Authors' acknowledgements}

This research was supported by grant number UM16-08 from the U.S. Social Security Administration (SSA) through the Michigan Retirement Research Consortium (MRRC). The opinions and conclusions expressed are solely those of the authors and do not represent the opinions or policy of SSA or any agency of the federal government. 


\section{Introduction}

As countries around the world grapple with the economic impacts of population aging, one policy recommendation has emerged above the rest: encourage older workers to extend their working lives. Increased employment at older ages would help offset the expected slowdown in economic growth caused by population aging and would also improve the fiscal balance of social security programs. But while the benefit of longer work lives may be clear, it is less clear what types of working conditions make work sustainable over a longer work life and therefore increase the likelihood of working at older ages. In this paper, we highlight key differences in the working conditions of older versus younger workers using data from the 2015 American Working Conditions Survey (AWCS).

The data come from a survey fielded between July 15 and October 15, 2015, to participants in the RAND American Life Panel (ALP). The ALP is a nationally representative (when weighted) sample of individuals residing in the U.S. who have agreed to participate in regular online surveys. Respondents who do not have a computer at home are provided both a computer and internet access, so that the panel is representative of all individuals in the U.S., not just Internet users. Since its inception in 2006, the ALP has fielded over 400 surveys on a wide variety of topics including health, employment and retirement. All surveys are publicly available (after an embargo period) and can be linked to one another. For more details about the RAND ALP, see https://alpdata.rand.org.

The AWCS includes several questions that are harmonized with the concurrently fielded European Working Conditions Survey (EWCS), now in its $6^{\text {th }}$ wave of data collection (since it began in 1991). For more about the EWCS, see http://www.eurofound.europa.eu/europeanworking-conditions-surveys-ewcs. The AWCS collected information on several dimensions of 
working conditions chosen because they are particularly relevant for understanding work sustainability. We also collected general information about the job/firm (number of workers, tenure), work-life balance, managerial support and detailed health information. Additionally, the AWCS includes information on nonworkers - when they last worked, why they left their last job, current job search activities, perceived barriers to finding work and preferences over job attributes. However, in this report we focus on workers only (including the self-employed).

Below we highlight key differences in American working conditions by age. We divide the sample into three age groups: ages 25-34, 35-49, and 50-71. Unless otherwise noted, all group differences described in the text are statistically significant at the 5 percent level. For more details on the survey and sample selection criteria, see Section 2 of Maestas et al. (2017); for a description of American working conditions by age, gender and education more generally, see Section 4 of the main report. To maintain consistency, we use the same numbering scheme for tables and figures as in the main report.

\section{The Timing and Location of Work}

Overall, eight in ten American workers describe their main job as "regular, steady work throughout the year." The remaining two in ten workers are evenly split between "predictable seasonal work during the year" and "unpredictable or irregular work (e.g., unpredictable periods without work, layoffs, and/or sporadic hours).” Regular, steady work is slightly more common for prime-age workers (ages 35-49) than for younger or older workers, and predictable seasonal work is less common for prime-age workers.

While the vast majority of Americans have steady and predictable work throughout the year, far fewer work the same number of hours on a day-to-day or weekly basis. Approximately 
one-half of men and 60 percent of women work the same number of hours every day and similar percentages work the same number of hours every week. (Table 4.1). Among those without a college degree, younger men are less likely than older men to work the same number of hours each day or each week. While work hours become more stable with age among those without a college degree, the opposite is true for those who have a college degree. Older college-educated men and women are less likely than their younger counterparts to work the same number of hours each day or each week. This age pattern could reflect the demands of career advancement for some, while for others it could arise from a preference for flexible hours. Overall, the data in Table 4.1 suggest substantial variability in working hours for Americans that is unequally distributed across the population, especially by education. The fact that variability rises with age among higher educated workers suggests that some of this variability may be by choice.

To explore the element of choice in working arrangements, Table 4.2 summarizes responses to the question, “How are your working time arrangements set?” Thirty-eight percent of men and 35 percent of women have the most restrictive possible arrangement, with their hours "set by company with no possibility for changes." Another 11 percent of men and 11 percent of women "can choose between several fixed schedules," while 35 percent of men and 41 percent of women "can adapt working hours within certain limits.” At the extreme, just 16 percent of men and 14 percent of women can fully determine their schedule ("working hours entirely determined by me"). Overall, Table 4.2 suggests that most Americans have some choice in setting their schedule, though for the vast majority, the company plays an important role in schedule setting. Choice over one's schedule is unequally distributed by education, with collegeeducated workers having substantially more control over their schedule. Older, college-educated men stand out as having the most freedom to determine their schedules. 
Workers with little or no choice of schedules are often subject to frequent and unpredictable changes to their work schedule (Figure 4.1). We asked workers, "Do changes to your work schedule occur often?” with the following response categories: "No," "Yes, the same day," "Yes, the day before," "Yes, several days in advance," and "Yes, several weeks in advance.” Non-college-educated workers are most prone to frequent changes in their work schedule, with younger workers more often subject to frequent changes than older workers. For example, seven percent of young non-college-educated workers frequently experience changes to their work schedule the same day and another three percent frequently experience changes with notice the day before. Altogether, approximately one in five non-college educated workers who are either young or prime age are subject to frequent changes to their work schedule, and nearly half the time these changes are made with little or no notice.

Relatedly, we asked respondents whether they can choose where they work during regular business hours. Over 80 percent of American workers without a college degree cannot choose where they work (with no significant differences between men and women). College educated men are least constrained in this regard; 64 percent of men with a college degree cannot choose where they work compared to 74 percent of college educated women. There were no significant differences across age groups.

While presence at the work place during business hours is required for most Americans, many take work home. More than half of American workers do some work in their free time in order to meet work demands (Table 4.3). Approximately one in ten workers report working in their free time "nearly every day" over the last month, two in ten workers report working in their free time "once or twice a week," and two in ten workers report working in their free time "once 
or twice a month.” College-educated workers—particularly younger, college-educated men—are more likely to work in their free time than non-college-educated workers.

While many Americans regularly adjust their personal schedules to accommodate work matters (Table 4.3), we also asked about the reverse: how easily could they adjust their work schedules to accommodate personal matters. Approximately 40 percent of younger workers without a college degree report difficulty arranging for time off during work hours to take care of personal or family matters (Figure 4.2) and one-quarter of this group also reports a poor fit between their working hours and their family or social commitments outside of work (Figure 4.3). By contrast, among young college-educated workers, only 29 percent report difficulty arranging for time off to attend to family matters and only 13 percent report a poor fit between their working hours and family lives. Older (age 50+) college-educated workers are least likely to have difficulty taking time off to attend to personal matters (22 percent) and are also least likely to report a poor fit between working hours and outside commitments (12 percent). Overall, a substantial fraction of young American workers feel constrained by their work schedules, presumably because this is a time of intense work effort for them (see Table 4.8) and also a period when many have small children.

\section{Physical and Social Risks in the Workplace}

American workers are subject to substantial physical demands in the workplace. Half of men and one-third of women have a job that involves lifting/moving people or carrying/moving heavy loads one quarter of the time or more frequently (Table 4.4). Forty-six percent of men and 35 percent of women have jobs involving tiring or painful positions one quarter of the time or more. About 40 percent of men and 30 percent of women work in jobs that involve standing all 
or almost all of the time. Older workers are less likely to have physically demanding jobs than younger workers. However, perhaps surprisingly, even older workers experience substantial physical demands.

In recent years there has been evidence linking sitting for long periods of time with allcause mortality, even after controlling for physical activity in other parts of the day (Chau et al., 2013). More than one-third of American men and more than half of American women work in jobs that involve sitting all or most of the time (Table 4.4). Somewhat surprisingly, the prevalence of prolonged sitting is substantially lower among older workers (ages 50+) than among younger and prime-age workers.

In addition to physical demands, a large number of individuals of all ages and both genders are exposed to unpleasant or potentially dangerous working conditions. Sixty-two percent of American men and 46 percent of American women are exposed to either vibrations (e.g., from hand tools or machinery), loud noise, extreme temperatures (high or low), smoke/fumes/powder/dust (including tobacco smoke) or vapors, or chemical products or infectious materials one quarter of the time or more in the course of their work. Table 4.5 presents these risks by gender, age and education. We found no significant differences by age.

Strikingly, nearly one in five American workers are subjected to some form of verbal abuse, unwanted sexual attention, threats or humiliating behavior at work in the past month, or to physical violence, bullying/harassment or sexual harassment at work in the past 12 months. These events are strongly correlated with age, with younger workers experiencing the most adverse social interactions. Broken down by type of event, 28 percent of young, non-college educated men report being subjected to verbal abuse or threats, 27 percent experienced humiliating behavior, and 4 percent reported receiving unwanted sexual attention in the past 
month; 11 percent reported being subjected to bullying or harassment (including sexual harassment) in the past year (Table 4.6); and 2 percent reported physical violence in the past year. The patterns among women are also alarming, especially with respect to unwanted sexual attention: 9 percent of young, college-educated women (age 25-35), 8 percent of young, noncollege educated women, and 7 percent of prime aged, non-college educated women (age 35-49) reported receiving unwanted sexual attention in the past month.

While the workplace is a source of hostile social experiences for an important fraction of American workers (Table 4.6), it is a source of supportive social experiences for many others (Table 4.7). More than half of American workers agreed with the statement "I have very good friends at work," with women more likely to report having very good friends at work than men. We asked employees who work for someone else whether they agreed or disagreed with the following statements about their immediate boss: "trusts you;” “respects you;” "gives praise/recognition;” "gets people to work together;” "is helpful;” “provides useful feedback;” and “encourages and supports your development.” Ninety-five percent of employees agreed with at least one of these statements about their boss and more than half (58 percent) agreed with all seven. Table 4.7 presents the percent of employees agreeing with all seven statements about their boss as well as those agreeing with the statements “you like \& respect your colleagues” “there is good cooperation between you \& colleagues,” and “conflicts are resolved fairly,”, by gender, education and age, respectively. Older workers are less likely than younger workers to have a very supportive boss, but are no more or less likely to say they like and respect their colleagues or have very good friends at work than their younger counterparts. 


\section{Work Intensity}

We next examine the intensity and pace of work. Approximately two-thirds of American workers work in jobs that involve working at very high speed at least half the time; the same fraction works to tight deadlines at least half the time (Table 4.8). The overlap is high, with 56 percent working in jobs that involve both working at high speed and to tight deadlines half the time or more. Older workers are significantly less likely than younger workers to both work at high speed and to tight deadlines.

Another measure of work intensity is how frequently workers perceive time constraints at work. We asked respondents how frequently they had enough time to finish their work, and categorized those answering “sometimes," "rarely” or “never” as time constrained. The age-bygender patterns reveal interesting nuances (Figure 4.7). For instance, among younger (under age 35) workers, men without a college degree are nearly three times more likely than comparable women to report not having enough time to finish their work (48 v. 15 percent). This gap closes with age (in fact slightly reverses) as perceived time constraints decline for men but rise for women. A similar age pattern exists for college educated men and women.

Finally, we asked respondents how often they have to interrupt a task they are doing in order to take on an unforeseen task. Half of American workers are interrupted “very” or “fairly” often (as opposed to “occasionally” or “never”). Of these, 40 percent viewed these interruptions as "somewhat negative” (as opposed to "without consequences" or "somewhat positive”). That is, one in five American workers is subjected to frequent disruptions in the course of their work. Strikingly, young (under age 35) men without a college degree are about as likely (at 22 percent) as the average worker to experience frequent disruptions at work, whereas young women without a college degree are more than half as likely (at 7 percent) as the average worker to experience 
frequent disruptions at work - this results in a three-fold difference between young men and women without college degree. Among non-college educated workers, frequent disruptions decline with age for men but rise somewhat for women, as was the case for perceived time constraints. Unlike perceived time constraints, among college-educated workers there are no significant differences between men and women at any point in the age distribution.

Overall, Table 4.8 indicates that most Americans frequently work at high speeds and under tight deadlines, and often perceive they have too little time to do their work. This paints a picture of a work environment that is often pressured, stressful and potentially physically taxing, corroborating (and perhaps contributing to) our earlier results on adverse physical and social job attributes. Among all potentially adverse job attributes, this is an area where differences by education are not as clear cut, since non-college educated workers more often have to work at high speed, whereas the college educated more frequently face tight deadlines. The one group that tends to fare better than average is older workers, who are less likely to work at high speeds, to tight deadlines, or to perceive time constraints than their younger counterparts.

\section{Autonomy and Creativity}

American workers have a great deal of autonomy in the workplace. Seventy-five percent are able to choose or change the order of tasks, 72 percent can choose or change their methods of work, and 78 percent can choose or change the speed or rate of their work (Table 4.9). There were no significant differences in these measures by age.

Thirty-three percent of men and 28 percent of women have a say in choosing their working partners (always or most of the time), with men significantly more likely to have a say than women. Although there is no clear age pattern among men, there is a strong age gradient in 
the ability to take breaks among women, especially women without a college degree. While only 39 percent of young (under age 35) women without a college degree are able to take breaks when they choose, 62 percent of older (age 50+) women without a college degree have their choice of break times.

American workers tend to have many opportunities to exercise creativity at work, although at the same time many jobs also involve monotonous tasks (Table 4.10). Interestingly, younger workers are more likely than older workers to hold jobs with complex tasks and that involve learning new things. Respondents were also asked how often they were able to apply their own ideas at work. Eighty-five percent report being able to apply their own ideas "sometimes," "most of the time” or "all of the time." There are no significant age differences in the ability to apply one's own ideas at work. Older workers are less likely than younger workers to have jobs that involve complex tasks and learning new things, but they are also significantly less likely than younger workers to work in monotonous jobs.

Overall, Table 4.10 paints a nuanced picture of autonomy in U.S. jobs. While a large fraction of Americans holds jobs whose tasks are typically monotonous, an overwhelming majority views 'solving unforeseen problems' and 'applying own ideas' as integral parts of their jobs. Similarly, most American workers report their jobs involve complex tasks and learning new things. As perhaps expected, older workers and more educated workers hold jobs that are less monotonous and have more opportunities to apply their own ideas. More educated workers and younger workers more often solve complex tasks and learn new things on the job. 


\section{Training, Opportunities for Advancement, and Meaning}

The need for training as well as opportunities to obtain training may change as workers age. Six percent of young (under age 35) workers without a college degree reports that they need further training to cope well with their duties in their current job, compared with 3 percent of prime age (ages 35-49) and 2 percent of older (ages 50+) workers without a college degree (Figure 4.9). Among workers with a college degree, unmet need for training is low and does not vary significantly with age. Consistent with this, older workers are marginally significantly more likely ( $<<0.10)$ to be overqualified in their current positions ("I have the skills to cope with more demanding duties.’) than are younger workers (40 percent versus 33 percent, respectively).

When it comes to receiving training, 43 percent of workers report having undergone training paid for or provided by their employer, 33 percent report having done training on their own initiative outside the workplace, 47 percent report having done training on their own initiative inside the workplace, and 54 percent received on-the-job training, all in the past 12 months (Table 4.11). Consistent with human capital theory, the prevalence of training declines with age. Older workers are less likely than younger workers to have undergone any type of training, especially on-the-job training. For example, 62 percent of men and 68 percent of women under age 35 report on-the-job training, compared with just 46 percent of men and 49 percent of women age 50 and older. One potential explanation for this differential comes from Figure 4.9; older workers are also less likely to report that they need further training.

Only 35-40 percent of workers report their job offers good prospects for career advancement. This implies that training does not necessarily correspond to aspirations. Moreover, perceived prospects for advancement vary in complex ways in the population - with 
young, college educated men and young, non-college educated women being most optimistic (Table 4.11).

Finally, we explored the degree to which American workers derive meaning and purpose from their work (Table 4.12). Specifically, we asked respondents how often their work provided them with the following: "opportunities to fully use talents;" “make positive impact on community/society;" "sense of personal accomplishment;" "goals to aspire to;" "satisfaction of work well done;” and “feeling of doing useful work.” Older workers report more sources of meaning than younger workers especially with respect to satisfaction of work well done, feeling of doing useful work and sense of personal accomplishment (Figure 4.10).

\section{Reference}

Maestas, Nicole, Kathleen J. Mullen, David Powell, Till von Wachter and Jeffrey Wenger (2017). “American Working Conditions.” RAND Technical Report TR-XXX. 
Table 4.1. Regularity of Work, by Gender, Education and Age

\begin{tabular}{|c|c|c|c|c|c|c|}
\hline \multirow[b]{2}{*}{ Do you work...?* } & \multicolumn{2}{|c|}{ All } & \multicolumn{2}{|c|}{ Non-College Graduate } & \multicolumn{2}{|c|}{ College Graduate } \\
\hline & Men & Women & Men & Women & Men & Women \\
\hline \multicolumn{7}{|c|}{ A. All Ages, 25-71 } \\
\hline Same number of hours every day & 49.0 & 59.2 & 48.9 & 65.0 & 49.2 & 50.2 \\
\hline Same number of days every week & 66.8 & 74.6 & 67.3 & 77.0 & 66.0 & 70.7 \\
\hline Same number of hours every week & 50.2 & 59.7 & 49.2 & 64.1 & 52.2 & 52.8 \\
\hline Fixed starting and finishing times & 45.9 & 53.7 & 50.1 & 60.5 & 38.1 & 43.0 \\
\hline Shifts & 31.4 & 33.4 & 37.7 & 44.6 & 19.7 & 15.9 \\
\hline \multicolumn{7}{|c|}{ B. Under Age 35} \\
\hline Same number of hours every day & 50.4 & 61.5 & 45.2 & 67.6 & 56.5 & 53.5 \\
\hline Same number of days every week & 63.5 & 75.5 & 65.8 & 78.7 & 60.8 & 71.2 \\
\hline Same number of hours every week & 56.0 & 63.8 & 52.2 & 65.3 & 60.4 & 61.8 \\
\hline Fixed starting and finishing times & 42.2 & 53.2 & 45.7 & 61.4 & 38.1 & 42.5 \\
\hline Shifts & 28.5 & 40.0 & 31.6 & 57.3 & 24.8 & 17.5 \\
\hline \multicolumn{7}{|c|}{ C. Ages 35-49 } \\
\hline Same number of hours every day & 49.1 & 59.8 & 48.6 & 63.3 & 50.6 & 53.6 \\
\hline Same number of days every week & 70.1 & 75.8 & 68.4 & 75.8 & 74.9 & 75.9 \\
\hline Same number of hours every week & 47.2 & 60.4 & 46.0 & 64.2 & 50.7 & 53.7 \\
\hline Fixed starting and finishing times & 48.4 & 54.8 & 49.6 & 58.8 & 45.0 & 47.7 \\
\hline Shifts & 37.8 & 36.6 & 44.6 & 46.0 & 18.9 & 20.0 \\
\hline \multicolumn{7}{|c|}{ D. Ages 50+ } \\
\hline Same number of hours every day & 47.9 & 57.3 & 51.7 & 65.1 & 40.8 & 45.1 \\
\hline Same number of days every week & 66.0 & 72.9 & 66.9 & 77.4 & 64.2 & 65.8 \\
\hline Same number of hours every week & 49.0 & 56.7 & 51.0 & 63.5 & 45.3 & 46.2 \\
\hline Fixed starting and finishing times & 46.2 & 53.0 & 53.5 & 61.7 & 33.0 & 39.3 \\
\hline Shifts & 26.9 & 26.5 & 33.3 & 36.3 & 15.3 & 11.2 \\
\hline
\end{tabular}

Sample: Ages 25-71, Working for Pay, N=2,024

*Response categories are not mutually exclusive.

Results weighted using raked sample weights. 
Table 4.2. Freedom to Set Work Schedule, by Gender, Education and Age

\begin{tabular}{|c|c|c|c|c|c|c|}
\hline \multirow[b]{2}{*}{ How are your working time arrangements set?* } & \multicolumn{2}{|c|}{ בAll } & \multicolumn{2}{|c|}{ " Non-College Graduate } & \multicolumn{2}{|c|}{ College Graduate } \\
\hline & Men & Women & Men & Women & Men & Women \\
\hline \multicolumn{7}{|c|}{ A. All Ages, 25-71 } \\
\hline Set by company with no possibility for changes & 37.5 & 34.8 & 47.9 & 40.1 & 18.0 & 26.6 \\
\hline Can choose between several fixed schedules & 10.8 & 10.7 & 11.5 & 12.9 & 9.3 & 7.1 \\
\hline Can adapt working hours within certain limits & 35.4 & 40.9 & 23.9 & 32.2 & 57.1 & 54.5 \\
\hline Working hours entirely determined by me & 16.3 & 13.6 & 16.7 & 14.8 & 15.6 & 11.8 \\
\hline \multicolumn{7}{|c|}{ B. Under Age 35} \\
\hline Set by company with no possibility for changes & 36.8 & 31.3 & 49.4 & 37.3 & 21.6 & 23.3 \\
\hline Can choose between several fixed schedules & 11.3 & 13.0 & 11.7 & 16.1 & 10.9 & 8.8 \\
\hline Can adapt working hours within certain limits & 36.7 & 46.1 & 18.8 & 32.9 & 58.2 & 63.4 \\
\hline Working hours entirely determined by me & 15.2 & 9.7 & 20.1 & 13.7 & 9.3 & 4.5 \\
\hline \multicolumn{7}{|c|}{ C. Ages 35-49 } \\
\hline Set by company with no possibility for changes & 37.2 & 37.9 & 44.5 & 42.9 & 16.6 & 29.0 \\
\hline Can choose between several fixed schedules & 11.8 & 11.2 & 13.1 & 13.5 & 8.1 & 7.3 \\
\hline Can adapt working hours within certain limits & 35.0 & 38.4 & 25.0 & 29.1 & 63.3 & 54.7 \\
\hline Working hours entirely determined by me & 16.0 & 12.5 & 17.5 & 14.5 & 12.0 & 8.9 \\
\hline \multicolumn{7}{|c|}{ D. Ages 50+ } \\
\hline Set by company with no possibility for changes & 38.5 & 34.0 & 51.1 & 38.7 & 15.4 & 26.7 \\
\hline Can choose between several fixed schedules & 9.2 & 8.8 & 9.4 & 10.7 & 8.8 & 5.8 \\
\hline Can adapt working hours within certain limits & 34.8 & 40.1 & 25.8 & 34.8 & 51.2 & 48.4 \\
\hline Working hours entirely determined by me & 17.5 & 17.1 & 13.6 & 15.8 & 24.6 & 19.1 \\
\hline
\end{tabular}

Sample: Ages 25-71, Working for Pay, N=2,023

*Response categories are mutually exclusive.

Results weighted using raked sample weights. 
Table 4.3. Working in Free Time, by Gender, Education and Age

\begin{tabular}{|c|c|c|c|c|c|c|}
\hline \multirow{2}{*}{$\begin{array}{l}\text { Over the last month, how often have you worked } \\
\text { in your free time in order to meet work } \\
\text { demands?* }\end{array}$} & \multicolumn{2}{|c|}{ All } & \multicolumn{2}{|c|}{ Non-College Graduate } & \multicolumn{2}{|c|}{ College Graduate } \\
\hline & Men & Women & Men & Women & Men & Women \\
\hline \multicolumn{7}{|c|}{ A. All Ages, 25-71 } \\
\hline Nearly every day & 9.6 & 11.1 & 9.8 & 9.8 & 9.3 & 13.3 \\
\hline Once or twice a week & 18.3 & 18.5 & 12.5 & 13.4 & 29.1 & 26.3 \\
\hline Once or twice a month & 21.3 & 21.4 & 18.0 & 19.5 & 27.4 & 24.5 \\
\hline I didn't work in my free time last month & 50.8 & 49.0 & 59.7 & 57.3 & 34.2 & 35.9 \\
\hline \multicolumn{7}{|c|}{ B. Under Age 35} \\
\hline Nearly every day & 11.0 & 9.0 & 14.5 & 6.6 & 6.8 & 12.1 \\
\hline Once or twice a week & 24.2 & 21.8 & 16.0 & 14.4 & 34.0 & 31.5 \\
\hline Once or twice a month & 24.2 & 25.6 & 23.7 & 24.9 & 24.9 & 26.4 \\
\hline I didn't work in my free time last month & 40.6 & 43.6 & 45.8 & 54.0 & 34.3 & 29.9 \\
\hline \multicolumn{7}{|c|}{ C. Ages 35-49 } \\
\hline Nearly every day & 7.4 & 13.7 & 6.6 & 13.4 & 9.6 & 14.2 \\
\hline Once or twice a week & 13.1 & 19.4 & 10.6 & 16.0 & 19.9 & 25.3 \\
\hline Once or twice a month & 21.6 & 19.7 & 16.3 & 18.6 & 36.5 & 21.7 \\
\hline I didn't work in my free time last month & 57.9 & 47.3 & 66.5 & 52.1 & 34.0 & 38.9 \\
\hline \multicolumn{7}{|c|}{ D. Ages 50+ } \\
\hline Nearly every day & 10.9 & 10.0 & 10.6 & 7.9 & 11.4 & 13.2 \\
\hline Once or twice a week & 19.2 & 15.6 & 12.5 & 10.4 & 31.5 & 23.8 \\
\hline Once or twice a month & 18.7 & 20.7 & 16.4 & 17.4 & 23.0 & 25.8 \\
\hline I didn't work in my free time last month & 51.2 & 53.7 & 60.6 & 64.3 & 34.1 & 37.1 \\
\hline
\end{tabular}

Sample: Ages 25-71, Working for Pay, N=2,018

*Response categories are mutually exclusive.

Results weighted using raked sample weights. 
Table 4.4. Physical Demands, by Gender, Education and Age

\begin{tabular}{|c|c|c|c|c|c|c|}
\hline \multirow[b]{2}{*}{ Does your main paid job involve...?* } & \multicolumn{2}{|c|}{ All } & \multicolumn{2}{|c|}{ Non-College Graduate } & \multicolumn{2}{|c|}{ College Graduate } \\
\hline & Men & Women & Men & Women & Men & Women \\
\hline \multicolumn{7}{|c|}{ A. All Ages, 25-71 } \\
\hline Moving heavy loads or people ( $1 / 4$ time++$)$ & 53.7 & 34.7 & 67.9 & 42.9 & 27.2 & 22.3 \\
\hline Tiring or painful positions ( $1 / 4$ time +$)$ & 46.1 & 34.8 & 56.6 & 42.9 & 26.3 & 22.2 \\
\hline Repetitive hand/arm movements (1/4 time+) & 74.1 & 75.6 & 81.5 & 80.6 & 60.2 & 68.0 \\
\hline Standing (all or almost all of the time) & 37.9 & 30.1 & 49.9 & 38.2 & 15.5 & 17.6 \\
\hline Sitting (all or almost all of the time) & 36.9 & 53.0 & 29.8 & 49.5 & 50.2 & 58.4 \\
\hline \multicolumn{7}{|c|}{ B. Under Age 35} \\
\hline Moving heavy loads or people ( $1 / 4$ time+ $)$ & 58.8 & 40.9 & 81.5 & 55.1 & 31.8 & 22.7 \\
\hline Tiring or painful positions (1/4 time+) & 50.5 & 38.5 & 65.8 & 53.8 & 32.3 & 18.9 \\
\hline Repetitive hand/arm movements (1/4 time+) & 80.0 & 75.9 & 89.1 & 80.1 & 69.1 & 70.7 \\
\hline Standing (all or almost all of the time) & 39.7 & 42.1 & 59.3 & 58.2 & 16.5 & 21.6 \\
\hline Sitting (all or almost all of the time) & 37.5 & 56.6 & 20.8 & 49.6 & 57.3 & 65.4 \\
\hline \multicolumn{7}{|c|}{ C. Ages 35-49 } \\
\hline Moving heavy loads or people (1/4 time+) & 55.9 & 39.4 & 66.3 & 46.7 & 26.8 & 26.8 \\
\hline Tiring or painful positions (1/4 time+) & 50.5 & 31.7 & 61.6 & 38.6 & 19.6 & 20.0 \\
\hline Repetitive hand/arm movements (1/4 time+) & 73.7 & 77.5 & 80.5 & 82.2 & 54.6 & 69.4 \\
\hline Standing (all or almost all of the time) & 39.1 & 30.3 & 47.9 & 36.8 & 14.6 & 19.3 \\
\hline Sitting (all or almost all of the time) & 41.9 & 56.6 & 39.5 & 52.8 & 48.5 & 63.3 \\
\hline \multicolumn{7}{|c|}{ D. Ages 50+ } \\
\hline Moving heavy loads or people (1/4 time+) & 47.6 & 26.8 & 61.1 & 32.6 & 23.0 & 17.9 \\
\hline Tiring or painful positions (1/4 time+) & 38.0 & 35.5 & 44.7 & 41.4 & 25.7 & 26.4 \\
\hline Repetitive hand/arm movements (1/4 time+) & 70.0 & 73.7 & 77.7 & 79.4 & 55.8 & 64.9 \\
\hline Standing (all or almost all of the time) & 35.3 & 22.9 & 46.3 & 28.9 & 15.4 & 13.6 \\
\hline Sitting (all or almost all of the time) & 31.3 & 47.6 & 23.9 & 46.4 & 44.6 & 49.5 \\
\hline
\end{tabular}

Sample: Ages 25-71, Working for Pay, N=2,006

*Response categories are not mutually exclusive.

Results weighted using raked sample weights. 
Table 4.5. Physical Risks, by Gender, Education and Age

\begin{tabular}{|c|c|c|c|c|c|c|}
\hline \multirow{3}{*}{$\begin{array}{l}\text { Are you exposed at work (at your } \\
\text { MAIN JOB) to...more than } 1 / 4 \text { of the } \\
\text { time or more?* }\end{array}$} & \multirow{2}{*}{\multicolumn{2}{|c|}{ All }} & \multirow{2}{*}{\multicolumn{2}{|c|}{ Non-College Graduate }} & \multirow{2}{*}{\multicolumn{2}{|c|}{ College Graduate }} \\
\hline & & & & & & \\
\hline & Men & Women & Men & Women & Men & Women \\
\hline \multicolumn{7}{|c|}{ A. All Ages, 25-71 } \\
\hline Vibrations & 29.3 & 9.4 & 38.6 & 12.9 & 12.1 & 4.0 \\
\hline Noise & 38.7 & 19.5 & 48.6 & 24.1 & 20.1 & 12.3 \\
\hline Extreme temperatures (low or high) & 52.0 & 29.6 & 66.0 & 35.0 & 25.8 & 21.3 \\
\hline Breathing smoke/fumes/vapors & 29.3 & 16.6 & 38.8 & 23.1 & 11.5 & 6.4 \\
\hline Handling chem. products/infect. materials & 28.6 & 22.6 & 35.5 & 28.2 & 15.8 & 14.0 \\
\hline \multicolumn{7}{|c|}{ B. Under Age 35} \\
\hline Vibrations & 28.0 & 13.9 & 37.9 & 20.4 & 16.1 & 5.6 \\
\hline Noise & 32.3 & 24.9 & 39.9 & 31.0 & 23.3 & 17.2 \\
\hline Extreme temperatures (low or high) & 52.0 & 27.2 & 74.4 & 31.8 & 25.3 & 21.1 \\
\hline Breathing smoke/fumes/vapors & 28.4 & 23.4 & 39.9 & 35.1 & 14.8 & 8.4 \\
\hline Handling chem. products/infect. materials & 26.7 & 25.9 & 36.3 & 32.2 & 15.4 & 17.8 \\
\hline \multicolumn{7}{|c|}{ C. Ages 35-49 } \\
\hline Vibrations & 35.8 & 11.3 & 45.3 & 14.9 & 9.4 & 5.0 \\
\hline Noise & 43.0 & 20.4 & 52.0 & 25.0 & 17.7 & 12.5 \\
\hline Extreme temperatures (low or high) & 54.1 & 32.3 & 64.5 & 38.8 & 24.9 & 21.2 \\
\hline Breathing smoke/fumes/vapors & 34.4 & 16.7 & 43.8 & 21.8 & 7.8 & 8.0 \\
\hline Handling chem. products/infect. materials & 34.5 & 21.5 & 40.2 & 26.3 & 18.5 & 13.1 \\
\hline \multicolumn{7}{|c|}{ D. Ages $50+$} \\
\hline Vibrations & 23.6 & 5.1 & 31.0 & 7.0 & 10.2 & 2.1 \\
\hline Noise & 39.0 & 15.5 & 50.0 & 19.5 & 18.9 & 9.1 \\
\hline Extreme temperatures (low or high) & 49.8 & 28.4 & 62.3 & 32.9 & 26.9 & 21.5 \\
\hline Breathing smoke/fumes/vapors & 24.7 & 12.5 & 32.1 & 18.1 & 11.2 & 3.8 \\
\hline Handling chem. products/infect. materials & 24.0 & 21.9 & 29.4 & 27.9 & 14.1 & 12.5 \\
\hline
\end{tabular}

Sample: Ages 25-71, Working for Pay, $\mathrm{N}=2,005$

*Response categories are not mutually exclusive.

Results weighted using raked sample weights. 
Table 4.6. Abuse, Violence and Harrassment, by Gender, Education and Age

\begin{tabular}{|c|c|c|c|c|c|c|}
\hline \multirow{2}{*}{$\begin{array}{l}\text { Over the last [month/12 months], during } \\
\text { the course of your work have you been } \\
\text { subjected to...?* }\end{array}$} & \multicolumn{2}{|c|}{ All } & \multicolumn{2}{|c|}{ Non-College Graduate } & \multicolumn{2}{|c|}{ College Graduate } \\
\hline & Men & Women & Men & Women & Men & Women \\
\hline \multicolumn{7}{|c|}{ A. All Ages, 25-71 } \\
\hline Verbal abuse or threats (past month) & 13.1 & 12.4 & 15.6 & 13.9 & 8.4 & 10.0 \\
\hline Humiliating behavior (past month) & 9.8 & 7.9 & 12.5 & 8.3 & 5.0 & 7.4 \\
\hline Unwanted sexual attention (past month) & 0.8 & 4.9 & 0.9 & 6.3 & 0.7 & 2.7 \\
\hline Bullying/harrassment incl sexual (past year) & 9.6 & 11.0 & 10.5 & 11.8 & 7.7 & 9.8 \\
\hline Physical violence (past year) & 2.0 & 1.1 & 2.2 & 1.7 & 1.6 & 0.2 \\
\hline \multicolumn{7}{|c|}{ B. Under Age 35} \\
\hline Verbal abuse or threats (past month) & 18.5 & 14.8 & 28.0 & 16.6 & 7.1 & 12.5 \\
\hline Humiliating behavior (past month) & 17.6 & 7.3 & 27.4 & 10.2 & 6.1 & 3.6 \\
\hline Unwanted sexual attention (past month) & 2.4 & 8.2 & 3.9 & 7.6 & 0.6 & 8.9 \\
\hline Bullying/harrassment incl sexual (past year) & 10.6 & 13.1 & 10.5 & 13.2 & 10.7 & 13.0 \\
\hline Physical violence (past year) & 1.6 & 0.7 & 1.9 & 1.2 & 1.2 & 0.0 \\
\hline \multicolumn{7}{|c|}{ C. Ages 35-49 } \\
\hline Verbal abuse or threats (past month) & 11.4 & 14.3 & 12.6 & 16.5 & 8.1 & 10.3 \\
\hline Humiliating behavior (past month) & 8.3 & 7.1 & 10.1 & 5.5 & 3.3 & 9.8 \\
\hline Unwanted sexual attention (past month) & 0.2 & 5.0 & 0.0 & 7.4 & 0.9 & 0.8 \\
\hline Bullying/harrassment incl sexual (past year) & 11.2 & 9.7 & 12.9 & 10.0 & 6.2 & 9.2 \\
\hline Physical violence (past year) & 3.4 & 1.9 & 3.4 & 2.9 & 3.3 & 0.2 \\
\hline \multicolumn{7}{|c|}{ D. Ages 50+ } \\
\hline Verbal abuse or threats (past month) & 10.6 & 9.2 & 11.1 & 9.9 & 9.9 & 8.2 \\
\hline Humiliating behavior (past month) & 5.5 & 9.1 & 5.6 & 10.0 & 5.2 & 7.8 \\
\hline Unwanted sexual attention (past month) & 0.2 & 2.9 & 0.0 & 4.5 & 0.7 & 0.3 \\
\hline Bullying/harrassment incl sexual (past year) & 7.1 & 11.1 & 7.7 & 12.9 & 5.9 & 8.3 \\
\hline Physical violence (past year) & 0.8 & 0.7 & 0.9 & 0.9 & 0.6 & 0.3 \\
\hline
\end{tabular}

Sample: Ages 25-71, Working for Pay, N=2,005

*Response categories are not mutually exclusive.

Results weighted using raked sample weights. 
Table 4.7. Social Support at Work, by Gender, Education and Age

\begin{tabular}{|c|c|c|c|c|c|c|}
\hline & \multicolumn{2}{|c|}{ All } & \multicolumn{2}{|c|}{ Non-College Graduate } & \multicolumn{2}{|c|}{ College Graduate } \\
\hline & Men & Women & Men & Women & Men & Women \\
\hline \multicolumn{7}{|c|}{ A. All Ages, 25-71 } \\
\hline Has very good friends at work & 52.7 & 60.7 & 55.8 & 61.0 & 46.9 & 60.4 \\
\hline Supportive boss* & 60.4 & 55.1 & 56.3 & 54.4 & 68.1 & 56.1 \\
\hline Like and respect colleagues* & 77.3 & 79.6 & 75.1 & 77.0 & 81.5 & 83.7 \\
\hline Good cooperation with colleagues* & 80.0 & 77.4 & 77.4 & 73.0 & 84.9 & 84.3 \\
\hline Conflicts resolved fairly* & 56.8 & 56.3 & 55.5 & 54.0 & 59.3 & 59.8 \\
\hline \multicolumn{7}{|c|}{ B. Under Age 35} \\
\hline Has very good friends at work & 52.0 & 63.9 & 65.1 & 62.4 & 36.5 & 65.8 \\
\hline Supportive boss* & 69.3 & 60.9 & 57.9 & 62.7 & 81.2 & 58.4 \\
\hline Like and respect colleagues* & 78.9 & 78.6 & 80.2 & 75.3 & 77.5 & 83.0 \\
\hline Good cooperation with colleagues* & 77.6 & 75.4 & 68.8 & 71.8 & 87.3 & 80.2 \\
\hline Conflicts resolved fairly* & 54.7 & 59.8 & 53.6 & 60.7 & 55.9 & 58.6 \\
\hline \multicolumn{7}{|c|}{ C. Ages 35-49 } \\
\hline Has very good friends at work & 55.8 & 63.0 & 56.2 & 64.3 & 54.8 & 60.8 \\
\hline Supportive boss* & 60.3 & 54.3 & 60.0 & 50.6 & 61.0 & 60.8 \\
\hline Like and respect colleagues* & 79.4 & 80.3 & 78.9 & 75.8 & 80.8 & 87.9 \\
\hline Good cooperation with colleagues* & 84.6 & 79.0 & 85.4 & 73.1 & 82.4 & 89.2 \\
\hline Conflicts resolved fairly* & 59.5 & 59.5 & 60.4 & 55.4 & 56.8 & 66.6 \\
\hline \multicolumn{7}{|c|}{ D. Ages 50+ } \\
\hline Has very good friends at work & 49.9 & 56.8 & 49.3 & 56.9 & 51.1 & 56.6 \\
\hline Supportive boss* & 53.4 & 52.1 & 50.7 & 53.4 & 58.9 & 50.1 \\
\hline Like and respect colleagues* & 73.7 & 79.6 & 67.3 & 79.2 & 86.9 & 80.2 \\
\hline Good cooperation with colleagues* & 76.9 & 77.1 & 73.2 & 73.7 & 84.3 & 82.4 \\
\hline Conflicts resolved fairly* & 55.7 & 50.8 & 50.7 & 48.7 & 65.7 & 54.1 \\
\hline
\end{tabular}

Sample: Ages 25-71, Working for Pay, N=2,006

*Conditional on working for someone else (an employee)

Results weighted using raked sample weights. 
Table 4.8. Intensity of Work, by Gender, Education and Age

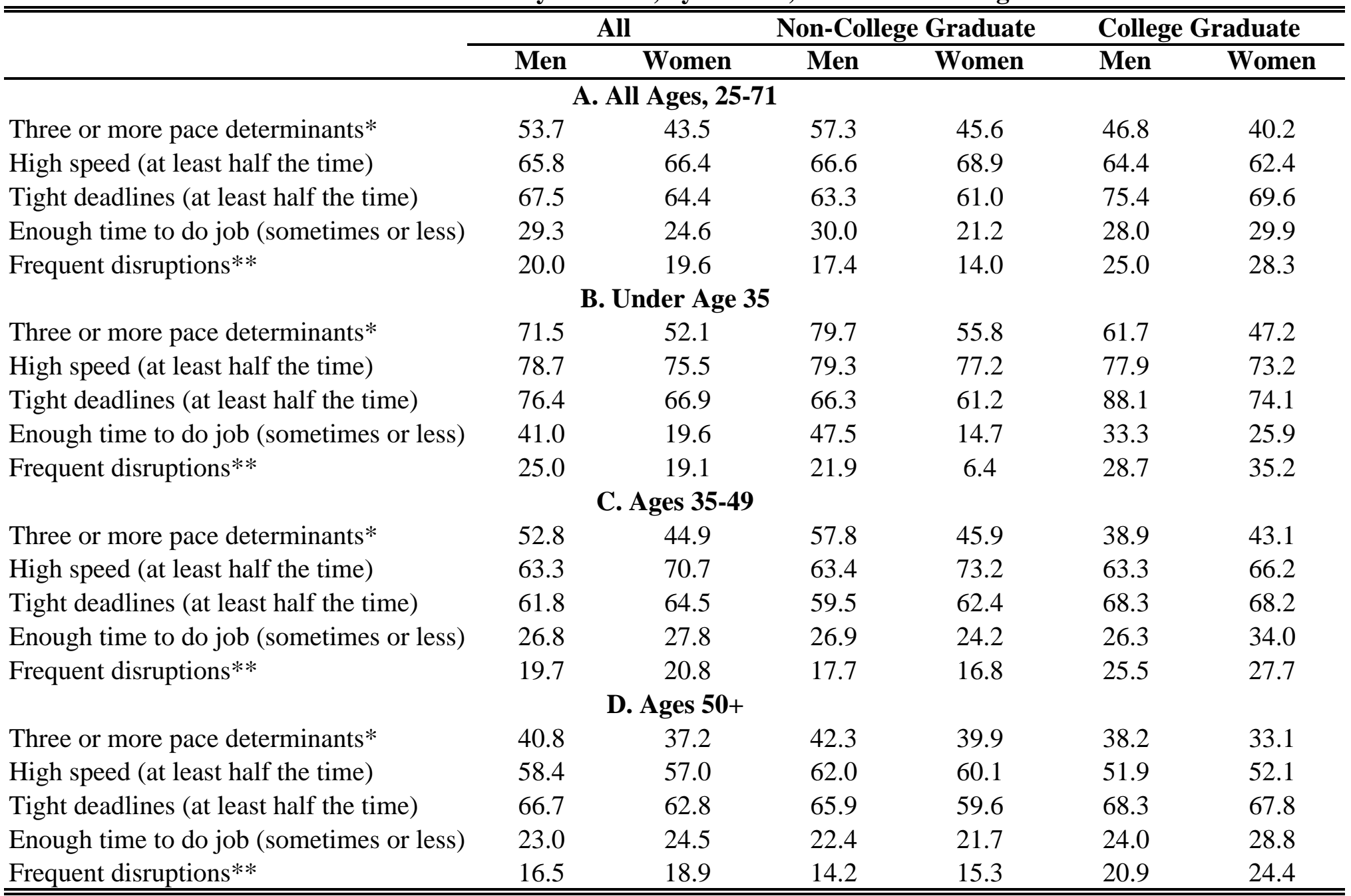

Sample: Ages 25-71, Working for Pay, N = 2,012

*See text for potential pace determinants (0-5). **Frequent disruptions defined by interrrupted "very" or "fairly" often and interruptions viewed as "somewhat negative."

Results weighted using raked sample weights. 
Table 4.9. Autonomy at Work, by Gender, Education and Age

\begin{tabular}{|c|c|c|c|c|c|c|}
\hline & \multicolumn{2}{|c|}{ All } & \multicolumn{2}{|c|}{ Non-College Graduate } & \multicolumn{2}{|c|}{ College Graduate } \\
\hline & Men & Women & Men & Women & Men & Women \\
\hline \multicolumn{7}{|c|}{ A. All Ages, 25-71 } \\
\hline Able to choose order of tasks & 72.5 & 76.9 & 66.4 & 70.6 & 83.8 & 86.8 \\
\hline Able to choose methods of work & 70.4 & 73.1 & 65.4 & 66.9 & 79.7 & 82.8 \\
\hline Able to choose speed/rate of work & 78.3 & 77.6 & 76.4 & 75.0 & 81.8 & 81.6 \\
\hline Have say in choice of working partners* & 33.2 & 27.5 & 35.2 & 24.8 & 29.4 & 31.7 \\
\hline Can take breaks when wanted* & 58.3 & 56.2 & 48.5 & 50.9 & 76.3 & 64.5 \\
\hline \multicolumn{7}{|c|}{ B. Under Age 35} \\
\hline Able to choose order of tasks & 72.2 & 75.4 & 65.0 & 67.1 & 80.8 & 86.1 \\
\hline Able to choose methods of work & 68.5 & 72.2 & 62.9 & 64.5 & 75.0 & 82.1 \\
\hline Able to choose speed/rate of work & 75.0 & 80.7 & 72.0 & 79.3 & 78.5 & 82.4 \\
\hline Have say in choice of working partners* & 37.2 & 29.1 & 45.4 & 28.9 & 27.5 & 29.3 \\
\hline Can take breaks when wanted* & 58.4 & 47.7 & 43.4 & 39.0 & 76.1 & 58.8 \\
\hline \multicolumn{7}{|c|}{ C. Ages 35-49 } \\
\hline Able to choose order of tasks & 70.6 & 75.9 & 65.5 & 70.8 & 84.8 & 84.8 \\
\hline Able to choose methods of work & 70.6 & 73.3 & 65.5 & 69.9 & 84.6 & 79.4 \\
\hline Able to choose speed/rate of work & 79.9 & 75.3 & 78.9 & 73.6 & 82.9 & 78.2 \\
\hline Have say in choice of working partners* & 31.8 & 28.3 & 34.4 & 25.5 & 24.3 & 33.1 \\
\hline Can take breaks when wanted* & 54.8 & 52.6 & 47.6 & 46.1 & 74.5 & 64.1 \\
\hline \multicolumn{7}{|c|}{ D. Ages 50+ } \\
\hline Able to choose order of tasks & 74.7 & 78.8 & 68.5 & 72.3 & 85.9 & 88.9 \\
\hline Able to choose methods of work & 71.7 & 73.5 & 67.0 & 65.3 & 80.5 & 86.3 \\
\hline Able to choose speed/rate of work & 79.2 & 78.0 & 76.4 & 74.1 & 84.3 & 84.2 \\
\hline Have say in choice of working partners* & 31.5 & 26.0 & 29.5 & 22.0 & 35.1 & 32.1 \\
\hline Can take breaks when wanted* & 61.7 & 64.6 & 52.9 & 62.0 & 77.8 & 68.6 \\
\hline
\end{tabular}

Sample: Ages 25-71, Working for Pay, $\mathrm{N}=2,014$

*Always or most of the time

Results weighted using raked sample weights. 
Table 4.10. Creative Work and Task Variation, by Gender, Education and Age

\begin{tabular}{|c|c|c|c|c|c|c|}
\hline \multirow{2}{*}{$\begin{array}{l}\text { Generally, does your main paid job } \\
\text { involve...?* }\end{array}$} & \multicolumn{2}{|c|}{ All } & \multicolumn{2}{|c|}{$\begin{array}{l}\text { Non-College Graduate } \\
\end{array}$} & \multicolumn{2}{|c|}{ College Graduate } \\
\hline & Men & Women & Men & Women & Men & Women \\
\hline \multicolumn{7}{|c|}{ A. All Ages, 25-71 } \\
\hline Solving unforeseen problems & 86.9 & 76.9 & 84.9 & 71.2 & 90.5 & 85.7 \\
\hline Complex tasks & 73.0 & 66.9 & 67.4 & 59.4 & 83.5 & 78.5 \\
\hline Learning new things & 83.8 & 83.6 & 82.1 & 80.5 & 86.9 & 88.4 \\
\hline Applying own ideas** & 84.1 & 86.2 & 80.1 & 82.0 & 91.5 & 92.7 \\
\hline Monotonous tasks & 62.5 & 60.7 & 63.7 & 62.8 & 60.3 & 57.4 \\
\hline \multicolumn{7}{|c|}{ B. Under Age 35} \\
\hline Solving unforeseen problems & 90.1 & 77.9 & 90.4 & 74.2 & 89.7 & 82.8 \\
\hline Complex tasks & 85.4 & 70.7 & 81.0 & 67.7 & 90.5 & 74.6 \\
\hline Learning new things & 92.0 & 87.8 & 90.8 & 85.3 & 93.3 & 90.9 \\
\hline Applying own ideas** & 84.3 & 86.6 & 80.6 & 81.6 & 88.8 & 92.9 \\
\hline Monotonous tasks & 72.4 & 66.1 & 75.8 & 65.9 & 68.3 & 66.3 \\
\hline \multicolumn{7}{|c|}{ C. Ages 35-49 } \\
\hline Solving unforeseen problems & 82.8 & 72.7 & 79.8 & 65.8 & 91.3 & 84.7 \\
\hline Complex tasks & 73.5 & 63.5 & 69.7 & 56.7 & 83.9 & 75.4 \\
\hline Learning new things & 81.8 & 82.1 & 82.0 & 78.3 & 81.3 & 88.8 \\
\hline Applying own ideas** & 79.8 & 86.3 & 75.4 & 82.8 & 92.0 & 92.5 \\
\hline Monotonous tasks & 66.2 & 61.4 & 66.2 & 63.3 & 66.3 & 58.3 \\
\hline \multicolumn{7}{|c|}{ D. Ages 50+ } \\
\hline Solving unforeseen problems & 88.6 & 80.2 & 87.4 & 74.9 & 90.7 & 88.5 \\
\hline Complex tasks & 63.0 & 67.8 & 55.7 & 57.7 & 76.3 & 83.8 \\
\hline Learning new things & 79.5 & 82.6 & 76.6 & 80.1 & 84.8 & 86.5 \\
\hline Applying own ideas** & 88.4 & 85.9 & 85.5 & 81.4 & 93.7 & 92.8 \\
\hline Monotonous tasks & 51.0 & 56.9 & 52.9 & 60.8 & 47.6 & 50.8 \\
\hline
\end{tabular}

Sample: Ages 25-71, Working for Pay, N = 2,014

*Question 49 unless otherwise specified. **Question q51f: "Able to apply your own ideas" at least sometimes.

Results weighted using raked sample weights. 
Table 4.11. Training and Prospects for Career Advancement, by Gender, Education and Age

\begin{tabular}{|c|c|c|c|c|c|c|}
\hline \multirow{2}{*}{$\begin{array}{l}\text { Over the past } 12 \text { months, have you undergone any of } \\
\text { the following types of training to improve your } \\
\text { skills?* }\end{array}$} & \multicolumn{2}{|c|}{ All } & \multicolumn{2}{|c|}{ Non-College Graduate } & \multicolumn{2}{|c|}{ College Graduate } \\
\hline & Men & Women & Men & Women & Men & Women \\
\hline \multicolumn{7}{|c|}{ A. All Ages, 25-71 } \\
\hline Paid for or provided by your employer & 41.3 & 45.8 & 34.4 & 39.2 & 54.2 & 56.1 \\
\hline Done on your own initiative outside workplace & 33.8 & 32.2 & 24.4 & 21.9 & 51.4 & 48.1 \\
\hline Done on your own initiative inside workplace & 47.4 & 46.4 & 42.4 & 41.0 & 56.7 & 54.5 \\
\hline On-the-job training & 52.6 & 55.8 & 48.6 & 53.4 & 60.2 & 59.6 \\
\hline Job offers good prospects for career advancement** & 40.5 & 34.6 & 39.5 & 33.3 & 42.3 & 36.7 \\
\hline \multicolumn{7}{|c|}{ B. Under Age 35} \\
\hline Paid for or provided by your employer & 45.1 & 55.6 & 34.9 & 46.9 & 57.1 & 66.6 \\
\hline Done on your own initiative outside workplace & 44.1 & 31.8 & 30.8 & 22.0 & 60.0 & 44.1 \\
\hline Done on your own initiative inside workplace & 48.4 & 53.0 & 37.8 & 48.5 & 60.8 & 58.8 \\
\hline On-the-job training & 62.1 & 68.0 & 51.8 & 62.8 & 74.3 & 74.6 \\
\hline Job offers good prospects for career advancement** & 53.7 & 44.9 & 46.8 & 44.9 & 62.0 & 44.8 \\
\hline \multicolumn{7}{|c|}{ C. Ages 35-49 } \\
\hline Paid for or provided by your employer & 39.1 & 43.5 & 34.7 & 36.6 & 51.3 & 55.5 \\
\hline Done on your own initiative outside workplace & 31.0 & 33.2 & 24.7 & 22.5 & 48.8 & 51.7 \\
\hline Done on your own initiative inside workplace & 49.9 & 44.1 & 47.9 & 39.7 & 55.8 & 51.8 \\
\hline On-the-job training & 52.6 & 56.2 & 51.2 & 52.6 & 56.7 & 62.4 \\
\hline Job offers good prospects for career advancement** & 43.8 & 35.8 & 47.0 & 30.9 & 35.2 & 44.3 \\
\hline \multicolumn{7}{|c|}{ D. Ages 50+ } \\
\hline Paid for or provided by your employer & 40.6 & 42.4 & 33.6 & 37.7 & 53.5 & 49.9 \\
\hline Done on your own initiative outside workplace & 28.7 & 31.5 & 19.8 & 21.3 & 44.9 & 47.4 \\
\hline Done on your own initiative inside workplace & 43.9 & 44.6 & 38.8 & 38.5 & 53.2 & 54.1 \\
\hline On-the-job training & 45.4 & 48.5 & 43.4 & 49.2 & 49.0 & 47.4 \\
\hline Job offers good prospects for career advancement ${ }^{* *}$ & 26.8 & 27.7 & 25.9 & 29.6 & 28.4 & 24.7 \\
\hline
\end{tabular}

Sample: Ages 25-71, Working for Pay, $\mathrm{N}=2,008$

*Question q61 unless otherwise specified; response categories not mutually exclusive. **Question q77c: Agree or strongly agree.

Results weighted using raked sample weights. 
Table 4.12. Meaningful Work, by Gender, Education and Age

\begin{tabular}{|c|c|c|c|c|c|c|}
\hline \multirow{2}{*}{$\begin{array}{l}\text { In general how often does your work } \\
\text { provide you with the following? }\end{array}$} & \multicolumn{2}{|c|}{ All } & \multicolumn{2}{|c|}{ Non-College Graduate } & \multicolumn{2}{|c|}{ College Graduate } \\
\hline & Men & Women & Men & Women & Men & Women \\
\hline \multicolumn{7}{|c|}{ A. All Ages, 25-71 } \\
\hline Satisfaction of work well done & 62.4 & 67.3 & 60.3 & 67.9 & 66.1 & 66.5 \\
\hline Feeling of doing useful work & 60.5 & 65.7 & 58.8 & 64.4 & 63.5 & 67.8 \\
\hline Sense of personal accomplishment & 59.4 & 63.0 & 57.8 & 61.1 & 62.4 & 66.0 \\
\hline Opportunities to fully use talents & 52.6 & 53.7 & 51.4 & 53.5 & 54.7 & 54.1 \\
\hline Make positive impact on community/society & 51.4 & 55.7 & 52.8 & 54.3 & 48.8 & 57.9 \\
\hline Goals to aspire to & 49.7 & 48.7 & 47.5 & 46.9 & 53.8 & 51.4 \\
\hline \multicolumn{7}{|c|}{ B. Under Age 35} \\
\hline Satisfaction of work well done & 59.4 & 63.7 & 58.6 & 68.6 & 60.4 & 57.4 \\
\hline Feeling of doing useful work & 52.6 & 61.2 & 56.0 & 62.8 & 48.7 & 59.2 \\
\hline Sense of personal accomplishment & 56.8 & 61.1 & 56.6 & 63.2 & 57.1 & 58.5 \\
\hline Opportunities to fully use talents & 51.7 & 49.5 & 54.9 & 53.8 & 47.9 & 44.0 \\
\hline Make positive impact on community/society & 52.7 & 53.8 & 64.1 & 54.7 & 39.2 & 52.7 \\
\hline Goals to aspire to & 49.3 & 48.5 & 47.5 & 51.0 & 51.4 & 45.2 \\
\hline \multicolumn{7}{|c|}{ C. Ages 35-49 } \\
\hline Satisfaction of work well done & 56.9 & 67.6 & 56.2 & 66.9 & 58.7 & 68.8 \\
\hline Feeling of doing useful work & 53.7 & 65.4 & 51.3 & 63.6 & 60.3 & 68.4 \\
\hline Sense of personal accomplishment & 51.6 & 61.0 & 50.9 & 56.4 & 53.2 & 69.1 \\
\hline Opportunities to fully use talents & 49.7 & 52.6 & 48.3 & 50.7 & 53.5 & 56.0 \\
\hline Make positive impact on community/society & 46.8 & 54.7 & 47.6 & 52.9 & 44.5 & 58.0 \\
\hline Goals to aspire to & 47.0 & 46.7 & 46.2 & 42.1 & 49.3 & 54.8 \\
\hline \multicolumn{7}{|c|}{ D. Ages 50+ } \\
\hline Satisfaction of work well done & 70.3 & 69.1 & 66.3 & 68.5 & 77.6 & 70.2 \\
\hline Feeling of doing useful work & 73.5 & 68.6 & 69.5 & 65.9 & 80.8 & 72.8 \\
\hline Sense of personal accomplishment & 69.5 & 66.1 & 66.7 & 64.7 & 74.7 & 68.1 \\
\hline Opportunities to fully use talents & 56.2 & 57.2 & 52.7 & 56.2 & 62.5 & 58.9 \\
\hline Make positive impact on community/society & 55.1 & 57.7 & 51.6 & 55.5 & 61.7 & 61.2 \\
\hline Goals to aspire to & 52.8 & 50.6 & 49.1 & 49.5 & 59.6 & 52.4 \\
\hline
\end{tabular}

Sample: Ages 25-71, Working for Pay, $\mathrm{N}=2,004$

Results weighted using raked sample weights. 


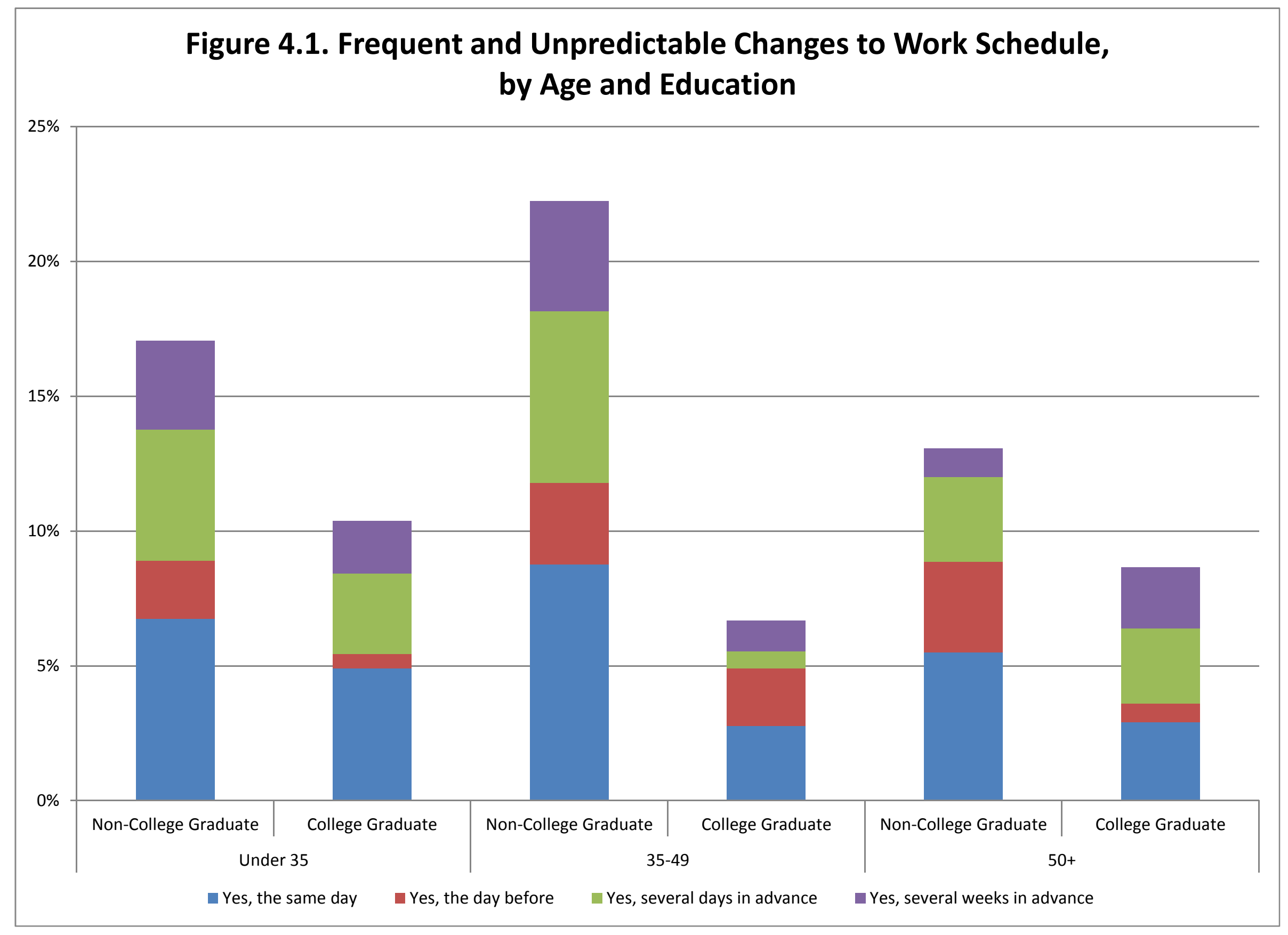




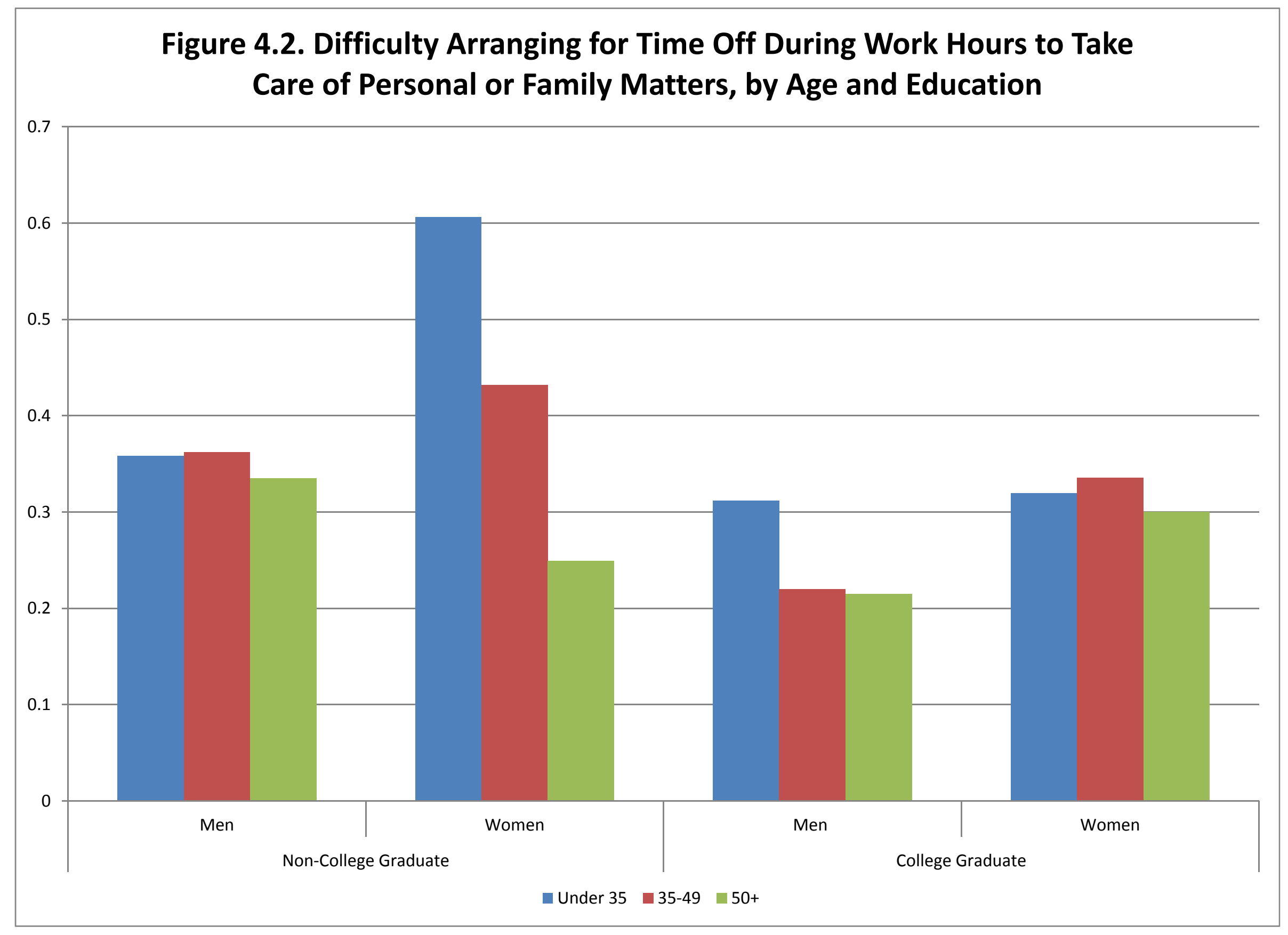




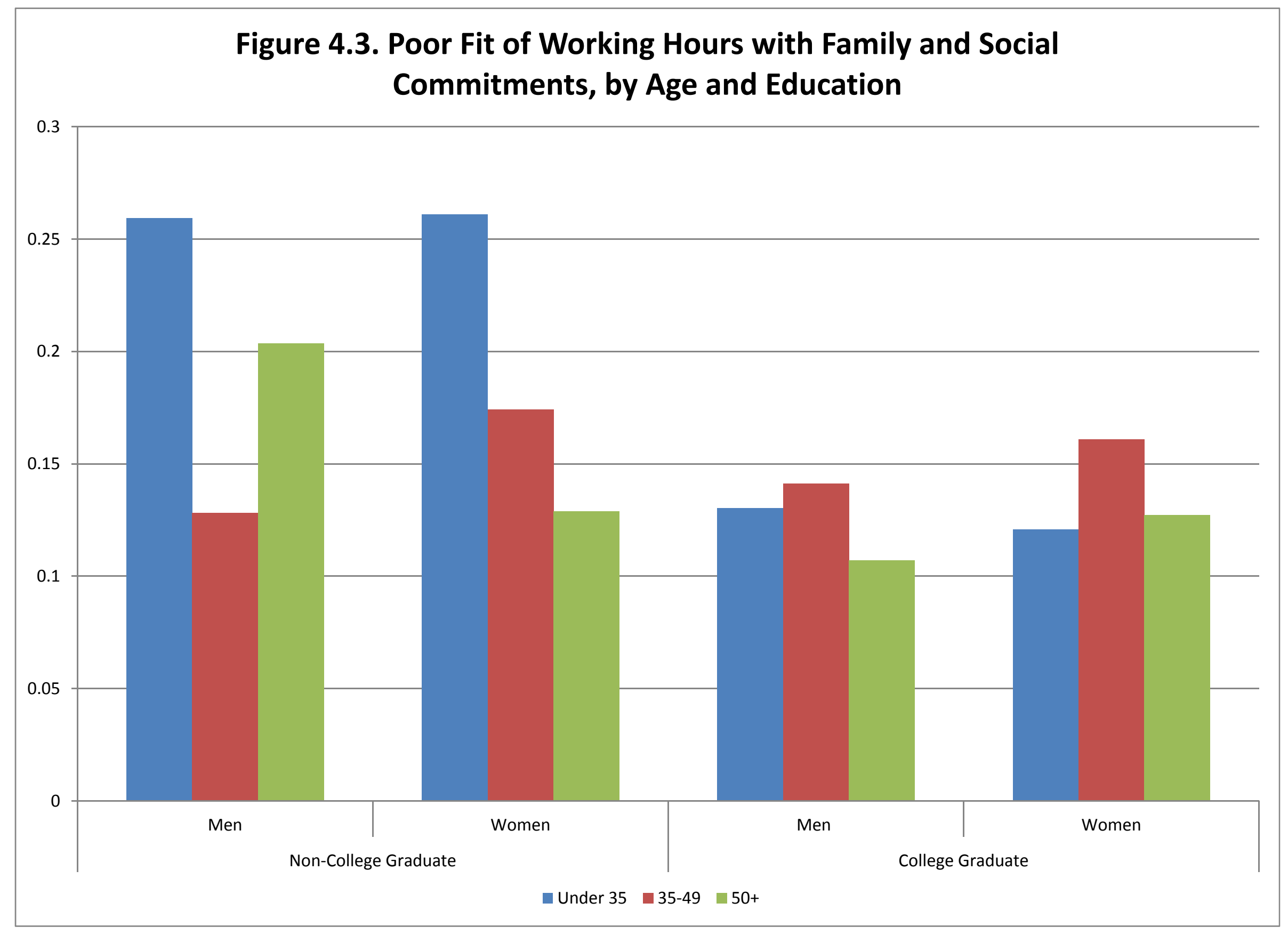




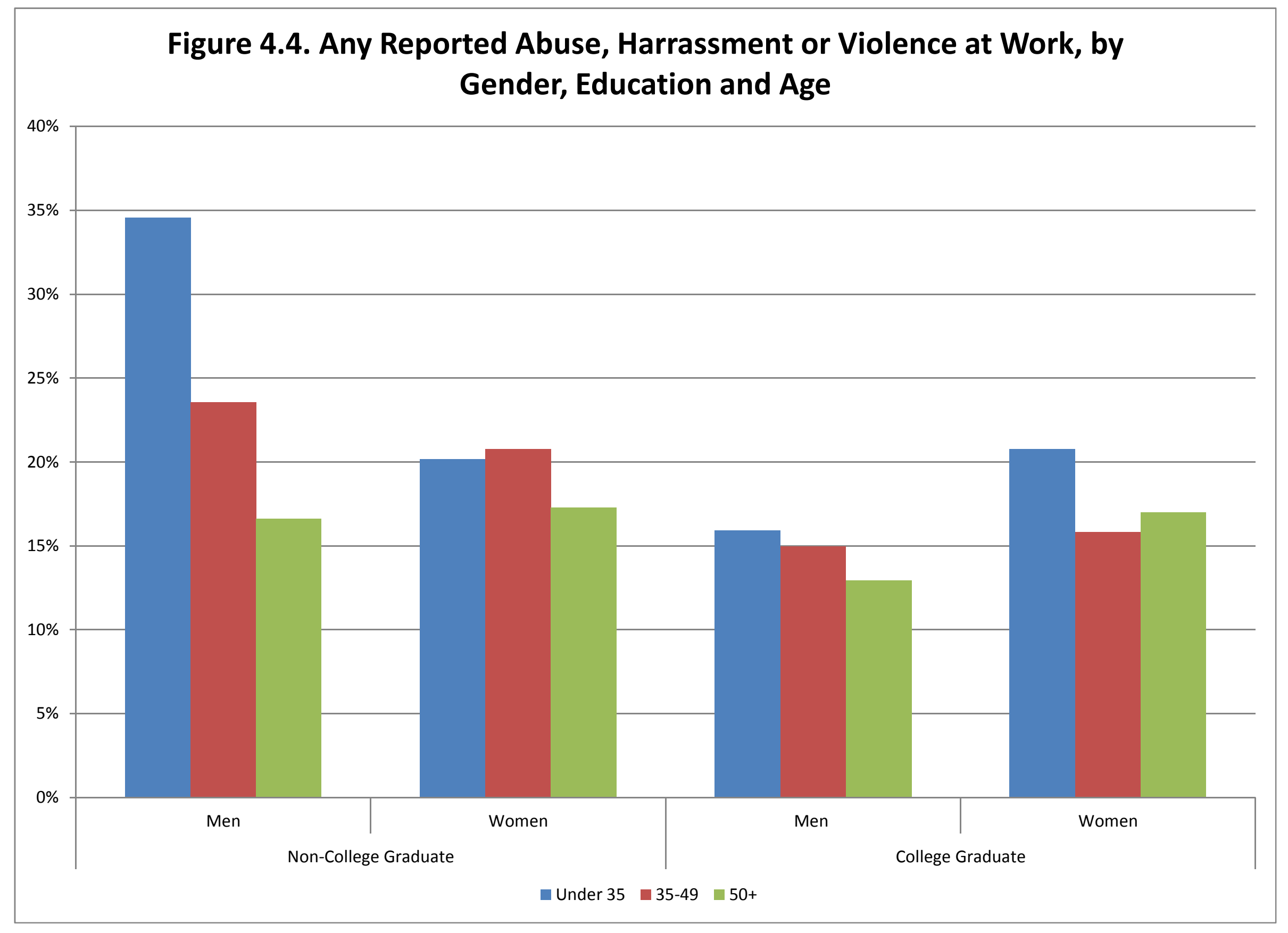




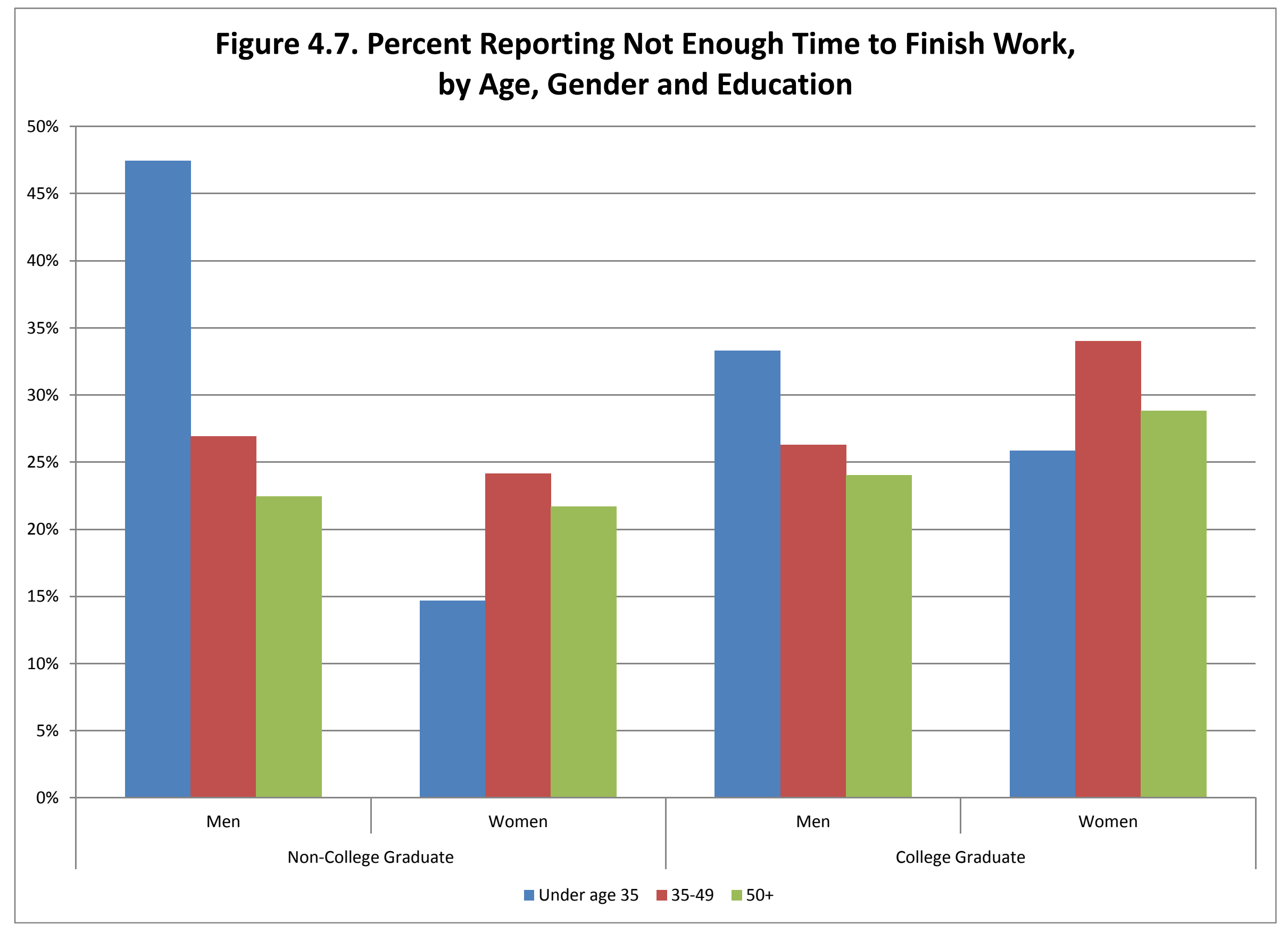




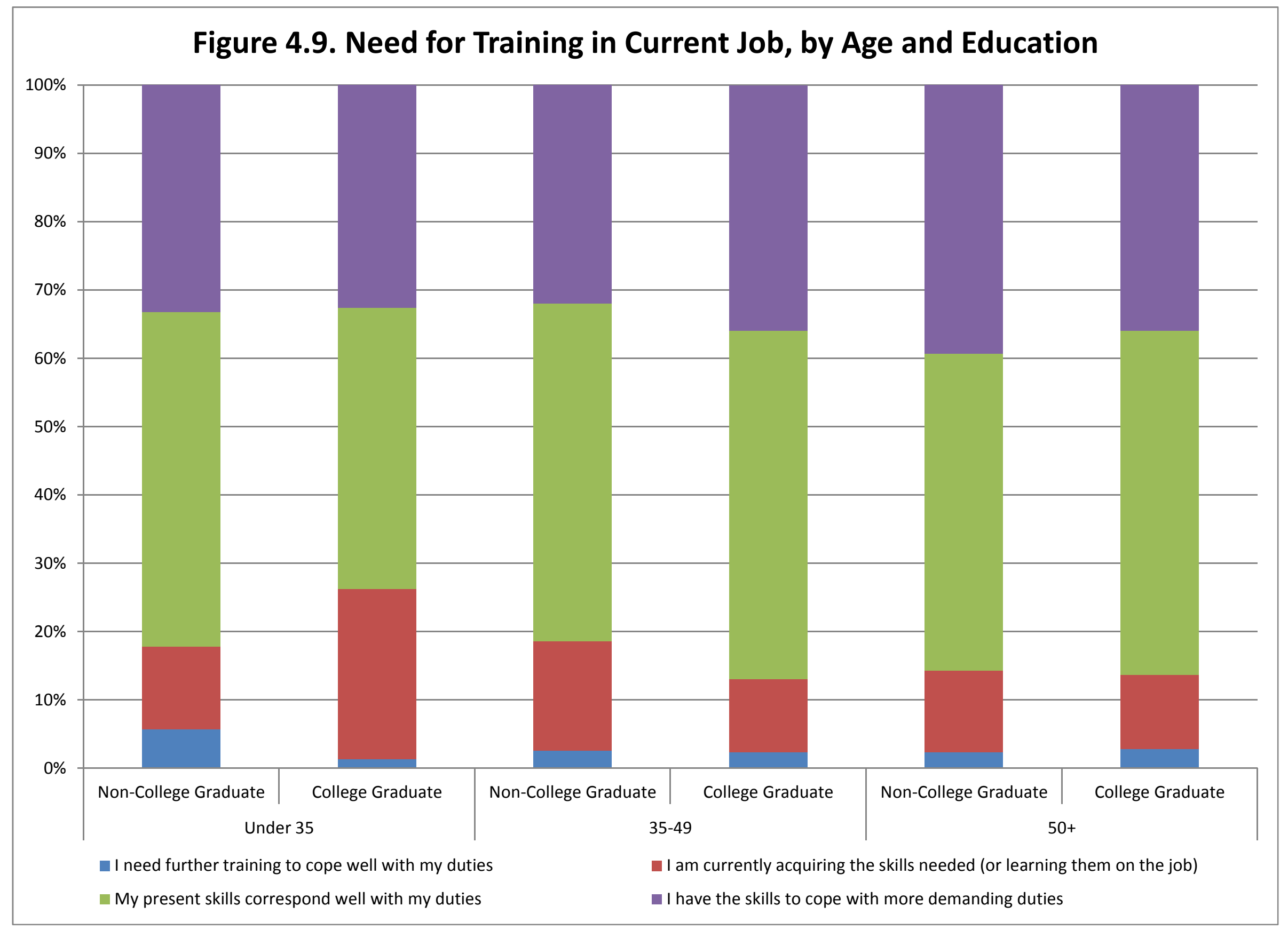




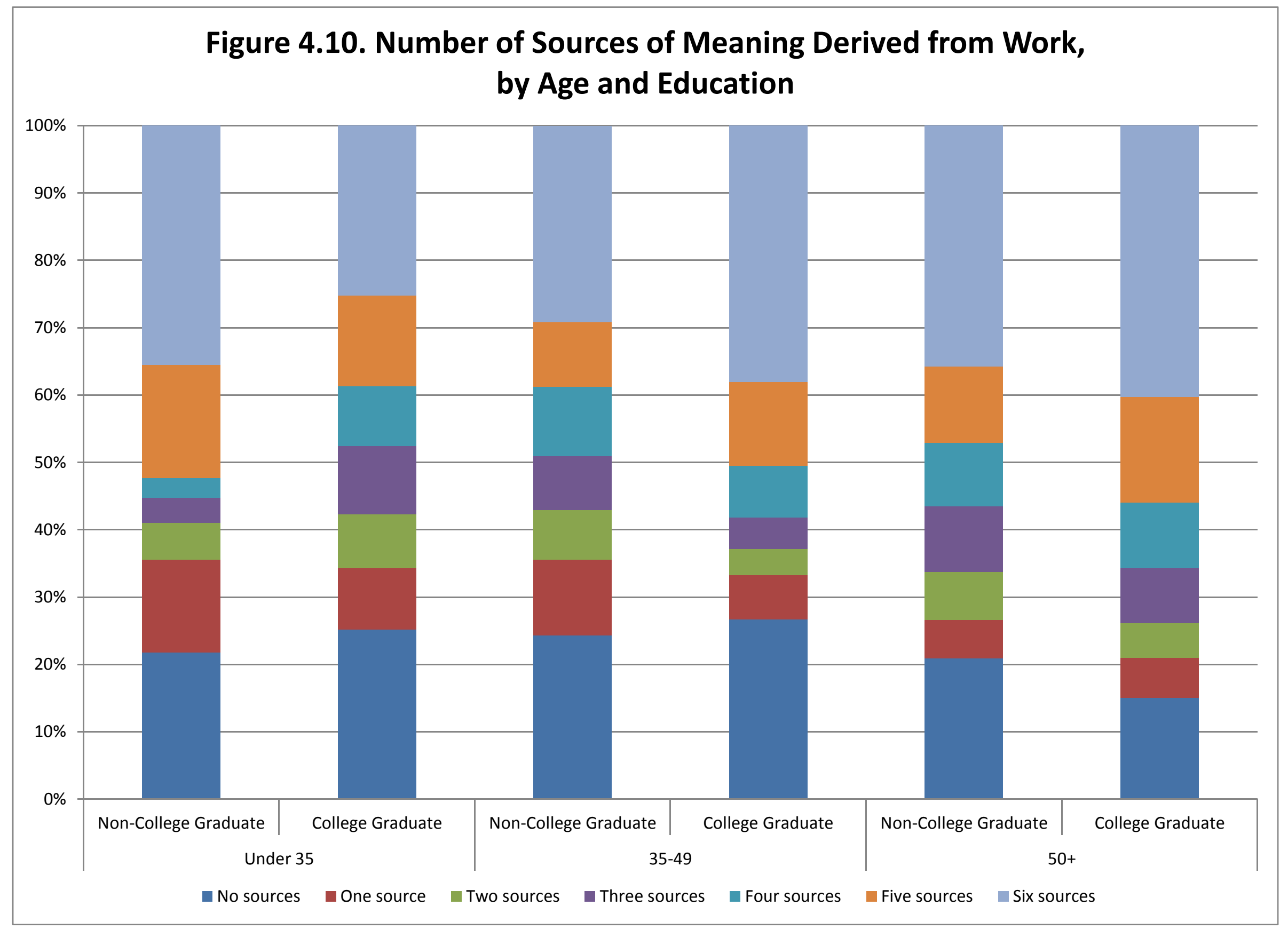

